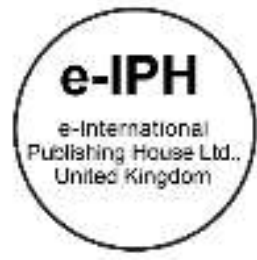

\title{
Re-maintaining Authentic Place Identity through Continuity: Sipiso-Piso, North Sumatera
}

\author{
Nurlisa Ginting ${ }^{1,2}$, Vinky Rahman ${ }^{1,2}$, Achmad Delianur ${ }^{1}$ \\ ${ }^{1}$ Department of Architecture, Faculty of Engineering, \\ 2Toba Lake \& Sustainable Tourism Working Group, \\ Universitas Sumatera Utara, 9 Dr. T. Mansyur Street, Medan 20155, Indonesia \\ nurlisa@usu.ac.id, n.vinky@usu.ac.id, a.delianur@usu.ac.id \\ Tel: +62811608102
}

\begin{abstract}
The current research observed continuity principle in maintaining the place identity of Sipiso-Piso, a tourist attraction in North Sumatera, in order to support Toba Caldera as National Strategic Tourism Area Priority. Striving to develop geo-tourism, Toba Caldera would face environmental and social risks arising instead of generating quality of life. A quantitative and qualitative approach were conducted to identify respondents' perceptions that indicates satisfying experiences. The result showed that since Sipiso-Piso merely offers the natural resources as the main attraction, the integrated planning related to tangible and intangible empowerment then is crucial due to the increasing number of tourists and demands from several tourists' parties.
\end{abstract}

Keywords: Place Identity; Continuity; Sipiso-Piso Waterfall; Toba Caldera

eISSN: 2398-4287 @ 2018. The Authors. Published for AMER ABRA cE-Bs by e-International Publishing House, Ltd., UK. This is an open access article under the CC BYNC-ND license (http://creativecommons.org/licenses/by-nc-nd/4.0/). Peer-review under responsibility of AMER (Association of Malaysian Environment-Behaviour Researchers), ABRA (Association of Behavioural Researchers on Asians) and cE-Bs (Centre for Environment-Behaviour Studies), Faculty of Architecture, Planning \& Surveying, Universiti Teknologi MARA, Malaysia.

DOI: https://doi.org/10.21834/e-bpj.v3i8.1399

\subsection{Introduction}

Geological assets, historical value, biodiversity, cultural diversity and ecological harmony have led Toba Caldera, the super-volcano in North Sumatera, Indonesia, to potentially developed geo-tourism area. Set as one of three main National Strategic Tourism Area priorities (KSPN) besides Lombok Island and Borobudur temple, Toba Caldera still requires further development to face the global competition.

The development of geo-tourism in the area, in fact, has been initiated through multisectoral establishment across Indonesian Ministry for some decades. Through Ministry of Tourism and Creativity Economy, Indonesia Government has prepared Lake Toba to be the member of UNESCO Global Geopark Networks (GGN) since 2011 by proposing it to UNESCO GGN, in two period times, November 2013 and November 2014 (Simatupang, 2016). In addition, the governor of North Sumatera was instructed to found acceleration teams to propose Geopark Caldera Toba to be one of UNESCO Global Geopark (UGG). However, the proposal was not successfully accepted as a Global Geopark in the 4th APGN Symposium held in San'in Kaigan Geopark, Japan, as it was considered immature (Simatupang, 2016). In 2017, the governor proposed again, and the result will be announced later in July 2018. Currently, Toba Caldera development is also supported by Ministry of Public Works and Housing through the improvement of quality, access and tourism infrastructure services (constructing road and bridge; affording clean water supply; providing affordable sanitation). This is done to strengthen local economy linkages to tourism, attract private investment and regulation ease.

eISSN: 2398-4287 @ 2018. The Authors. Published for AMER ABRA cE-Bs by e-International Publishing House, Ltd., UK. This is an open access article under the CC BYNC-ND license (http://creativecommons.org/licenses/by-nc-nd/4.0/). Peer-review under responsibility of AMER (Association of Malaysian Environment-Behaviour Researchers), ABRA (Association of Behavioural Researchers on Asians) and cE-Bs (Centre for Environment-Behaviour Studies), Faculty of Architecture, Planning \& Surveying, Universiti Teknologi MARA, Malaysia.

DOI: https://doi.org/10.21834/e-bpj.v3i8.1399 
Being a UGG can promote Toba Caldera tourism, attracting flock of tourists to come and bringing sustainable economic benefits. It will also increase quality of life as well as the conservation of nature, culture, aesthetics and heritage. It has been reported that geopark concept is a tool to help promote the global environmental sustainability (Simatupang, 2016). Unfortunately, in spite of providing job opportunity and generating quality of life by raising city profile, Toba Caldera geo-tourism could well face several challenges. Global competition, for example, is an indispensable development that highly encourages a tourism area to differentiate itself as an attractive destination, through promoting both tangible and intangible elements (Nurlisa et al., 2016). Another case is the tendency of developing an area without awareness of environmental and social risks, and this is also a dangerous threat to culture and local wisdom survival. The environmental changing could worryingly weaken the perception toward a city and influence people's sense of belonging (Yaldiz et al., 2014). In preserving the cultural value and revitalizing the environment, place identity would create the image of the place that indicates meaning, attachment, and place experience (Ujang, 2012). Therefore, the place identity in the area is crucial to maintain. Furthermore, creating a memorable and meaningful place should be a focus in securing place identity. The result showed that the value of physical elements, memory, and nostalgia strongly influence the continuity aspect in strengthening the authentic identity.

The objective of this paper is to examine the influences of continuity in constructing place identity in Sipiso-Piso, Merek Sub-district, in order to support Toba Caldera as a geo-tourism. Sipiso-Piso is a tourist destination spot in Harangaol geo-area which is considered as the most visited tourist attraction in Karo Regency. Unfortunately, the development of Sipiso-Piso merely offers the natural resources as the main attraction, and so the remarkable attraction (tangible and intangible elements) is crucial due to the increasing number of tourists and demands from several tourists' parties.

\subsection{Literature Review}

\subsection{Place Identity and Physical Degradation}

A place can reveal and affirm individual's identity since an environment has its symbolic value significantly related to one's social, emotional, and behavior (Lalli, 1992). The concept of identity shows how local environment (geographical location, cultural traditions, cultural heritage) affect lives (Fisher, 2006). The character of a well-formed and well-maintained place allows people to live well, comfortably and safely in their environment.

Along with the development of Toba Caldera as a tourism destination, the existence of historical building was diminished and transformed to the new modern building. This transformation has impacted people experienced and their feeling of psychological wellbeing. A disintegrated place meaning and attachment would threaten the character of place which indicates the image of the urban area. As a consequence, it would weaken or even lose the authentic identity. Therefore, it is essential to view a place as one component consists of a physical form, activity, and meaning (Ujang, 2015).

\subsection{Continuity Principle}

A place has an identity if any element forms it. One of the elements of place identification is continuity. The identity of the place has a continuity element if it has the same characteristics as in the past. This place can show the values contained therein to those who involved in (Twigger-Ross and Uzzell, 1996; Devine, 1994). These values are capable of providing personal experience (nostalgia and memory) from somewhere so that s/he is familiar with the place (Yuen, 2005). The value of an area can provide their own experience so it can be remembered that the region has a difference (Lalli, 1992).

Lalli (1992) presents five principles of place identity in an urban context, i.e., continuity, attachment, familiarity, commitment, and external evaluation. A place can support the continuity of a person's identity since the area has the same character as the person's previous residence, or it has a history of someone's life in the past. Twigger-Ross and Uzzell (1996) divide this principle into two part, i.e., place-referent continuity and place-congruent continuity. The place-referent continuity means the way a person identifies himself or his actions in the past by using the features of a place: providing "aide-memoire" (Korpela, 1989).

Meanwhile, place-congruent continuity is constructed from landscapes with specific characteristics. These are the memory of a person, reminding the person somewhere that is familiar with the person in the past and representing the same feelings as in the past. The place-congruent continuity is also referred to as an elective belonging in sociology (Savage et al., 2005), meaning to identify with a place, where the place matches the person's typical, or a place selected due to the values, ideas, lifestyles represented (Twigger-Ross and Uzzell, 1996). This continuity principle is also mentioned by Yuen (2005) which explained that place identity could help create sustainable value, shape, and conserve one's identity. Heritage buildings reflecting the past inheritance remind us that physical and time elements are two inseparable parts of lives.

Lalli (1992) states that one of place identity principles in the urban context is constructed through the past. This principle reflects the relationship between human biography and place, which is a symbol of personal experience. This aspect is well aligned with the principle of continuity in the Breakwell (1993) model. This is also explained by Korpela (1989) which demonstrated that there is a relationship between place identity and the environment (environmental self-regulation), and identity establishment is a process related to the sense of belonging or feeling to be part of an environment. Continuity is an essential aspect of the process of establishing place identity. The physical characteristics of a place are not the main thing but rather the values contain in; the continuity of one's values; and the memories of the area in such as nostalgia and experience. 


\subsection{Methodology}

\subsection{Research Area}

There are ten priority tourism destination (see Fig.1) that profoundly represents Toba Caldera and set by acceleration team proposing Geopark Caldera Toba (Ginting et al., 2017). Stretching out in eight regencies, Merek Sub-district located in Karo Regency is one of the destination priorities in developing Toba Caldera geo-tourism with the attractiveness of Sipiso-Piso Waterfall. Sipiso-Piso is located in Caldera Haranggaol Geo-area which concerns on Haranggaol, Tongging, Silalahi Geosite (see Fig.1). The geo-site was established in $500 \mathrm{ka}$, where the second eruption of Toba Caldera approximately occurred (Chesner, 2011)

Most research on built environment investigated by case studies such as Ujang (2012) and Twigger-Ross and Uzzell (1996). The current investigation concerns a built environment which examines the personal perception toward a place. The study chose Lake Toba Caldera as the primary interest. See on Presidential Regulation of Republic of Indonesia No. 81 of 2014 about Spatial Planning area of Lake Toba and surrounding, Merek Sub-district is one focus developing areas in $125,51 \mathrm{~km}^{2}$ with total population is 18.712 . Through pilot research conducted previously, Sipiso-Piso got the lowest perception of local people and tourists at the point 2.99 from Likert-scale despite its development is priority compared to the most frequently tourism destination visited in Karo Regency (Pasar Buah/fruit market, Bukit Gundaling/Gundaling Hill, Lingga Village, Bukit Kubu/Kubu Hill). The scale indicates the satisfied value revealed from respondents' perception toward the parameters ranging from "strongly agree" to "strongly disagree."

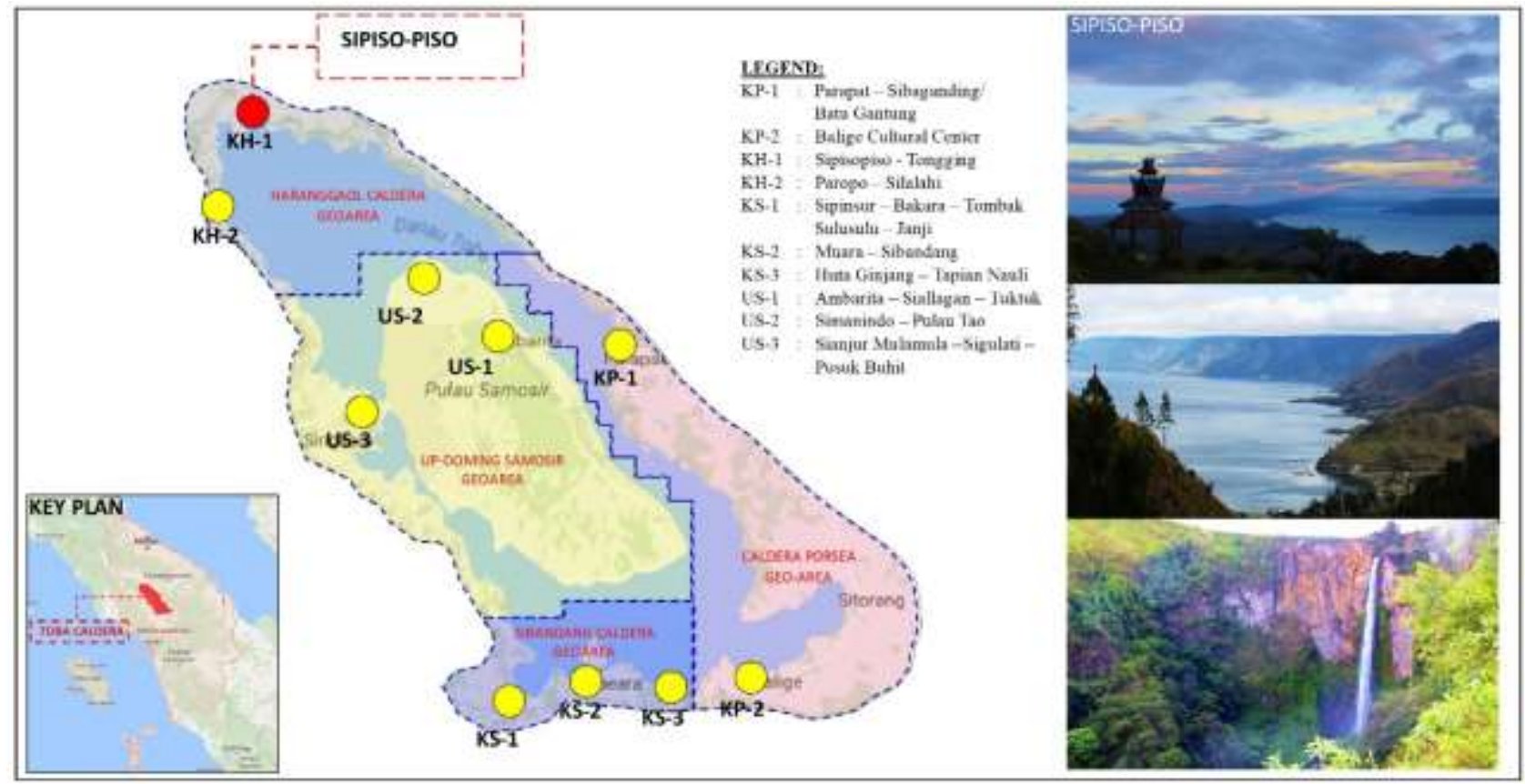

Fig. 1: Research Area

\subsection{The Method}

The research is generally based on one major issue-how place identity influences the tourism growth in the tourism destination related to the physical and perception of local people and tourists to get a distinct image. Tourist perception that indicates to satisfying experience is the main point in this research. Some critical aspects of a place will be considered in this research such as personal and socio-cultural respondents' characteristics, physical characteristics, activities, place significance, the principle of place identity, and the influence of place identity toward supporting tourism in the study area.

The research was conducted in 2016. The current finding is part of the investigation that concerns on continuity as one of place identity principles. This research employed a mixed-use method (qualitative and quantitative method) that provides an approach to the case through the induction process which is the most appropriate tool for investigating human and behavior. There are few research used mixed- method like Lobo (2004) which involved interviewing techniques and observations to make questionnaires in measuring common feelings and fundamental factors in the context of the community. Then, Ujang (2012) used a mixed-method as well as in the identification of a place's identity. The previous studies separate the physical aspects with emotional aspects of human experience in identifying the characteristics and meaning of the area. Hence, all issues, context, and parameters were determined by quantitative methods in the studies. Then, the findings were analyzed using qualitative methods that will gain comprehensible conclusions.

The quantitative approach of the current research was conducted by employing questionnaire survey of 72 respondents which was equally distributed to local people (residents, street, shopowners, shopkeepers) and tourists. Respondents were randomly selected based on the researcher's confidence and the willingness of the respondents to participate. The paramaters of the questionnaire survey provided were revaled the level of continuity principle in defining place identity (see on Table 1). 
The questionnaire question conducted as well as informed the information of profiles respondents including the occupation of local people, intentions, frequency, and duration of the visit which were provided in multiple choice. However, the analysis not profoundly connected to the engagement and dependency that related to the continuity. It becomes the limitation of the current research. The study should be revealed more to get any information related to not only provide the data. The result of the questionnaire then was processed statistically in SPSS 20. A Likert scale of 5 series ranging from "strongly agree" to "strongly disagree" is used to measure the questionnaire result that provided in percentage and average value.

Previously, compiling theory which cited references and theories about the identity of places and tourism and tourism, particularly continuity towards constructing place identity was conducted to define the limits of the research theory. Besides, the findings were analyzed using qualitative approach through eight in-depth interviews with tourism stakeholders and field observation to obtain the results. Face to face interview - with tourism stakeholders, traditional building owners, academics, and people who involved in Karo tourism development- was conducted with respondents to understand subjective and spontaneous feelings, motivation and the responses, meaning and importance of the area to respondents. Meanwhile, direct observation was performed to notice activity patterns and physical to create research variables. The result of qualitative data then was coded and separated into the same variables. Finally, researchers combined the results of quantitative and qualitative approach and researchers triangulated it to seek the convergence.

Table 1. Variables of Continuity Principle

\begin{tabular}{|c|c|}
\hline $\begin{array}{c}\text { Variables of } \\
\text { Continuity Principle }\end{array}$ & Parameter \\
\hline Value & $\begin{array}{l}\text { The attractiveness of social culture value } \\
\text { The attractiveness of historical value } \\
\text { The attractiveness of building value }\end{array}$ \\
\hline Nostalgia & Revealing memory of the past (birthplace, childhood) \\
\hline Familiarity & $\begin{array}{l}\text { Perception of physical quality } \\
\text { Perception of non-physical quality }\end{array}$ \\
\hline
\end{tabular}

\subsection{Result and Discussion}

\subsection{Respondents}

A total of 72 respondents was involved in the current research consisted of (36) local people and (36) tourist: 22 and 14 for domestic tourists and foreign tourists, respectively. The result shows that the respondents participated predominantly was adult to middle age group where more male was dominated (56\%). Malaysian tourists were dominant followed by Singapore and German. Mostly tourists visited with friends where having sightseeing became the primary motivation for tourist attended Sipiso-Piso. Meanwhile, of 36 local people in Sipiso-Piso, 28 people $(78 \%)$ have already inherited for five years or more where the majority of them were born from Karo Regency ( $n=26)$. The street vendors mostly sell food and souvenirs.

\subsection{Continuity Principle}

The mean score of the questionnaire survey is provided in Table 2. Mostly the respondents were amazed by the natural scenery offered. The table shows that perception of respondent both local people and tourist toward continuity principle.

Table 2. Continuity Prinicple in Sipiso-Piso Waterfall

\begin{tabular}{|c|c|c|c|c|}
\hline \multirow{3}{*}{ Indicators } & \multirow{3}{*}{ Statement } & \multirow{2}{*}{$\begin{array}{l}\text { Local } \\
\text { People }\end{array}$} & \multicolumn{2}{|c|}{ Tourist } \\
\hline & & & $\begin{array}{c}\text { Domestic } \\
\text { Tourists }\end{array}$ & $\begin{array}{l}\text { Foreign } \\
\text { Tourists }\end{array}$ \\
\hline & & Mean & Mean & Mean \\
\hline \multirow[t]{4}{*}{ Value } & I am interested in the cultural activities in this place & 2,86 & 3,05 & 3,64 \\
\hline & I am very impressed with the historical story in this place & 2,94 & 2,82 & 3,57 \\
\hline & I am interested in historical buildings in this place & 2,67 & 3,27 & 3,50 \\
\hline & This place is famous for its historical buildings & 2,64 & 3,05 & 3,50 \\
\hline \multirow[t]{4}{*}{ Nostalgia } & This place is my hometown & 2,72 & 2,36 & 0,00 \\
\hline & This place reminds me of my chilhood & 2,81 & 2,41 & 0,00 \\
\hline & I have a memorable experience in this place & 3,17 & 3,00 & 3,29 \\
\hline & I will visit this place later on / I will stay at this place later on & 3,14 & 2,27 & 3,29 \\
\hline \multirow[t]{5}{*}{ Familiarity } & The facilities at this place are appropriate & 2,67 & 2,45 & 3,36 \\
\hline & The accomodation/hotel in this place is clean and well- maintained & 2,64 & 2,64 & 3,43 \\
\hline & I was amazed by the natural scenery of this place & 3,50 & 3,50 & 3,64 \\
\hline & I was very impressed with the local wisdom in this place & 3,17 & 3,32 & 3,29 \\
\hline & The local people are friendly with tourists & 3,39 & 2,86 & 3,57 \\
\hline \multicolumn{2}{|c|}{ Value Format: 1 = strongly agree; 5 = strongly disagree } & 2,95 & 2,85 & 3,46 \\
\hline
\end{tabular}

\subsubsection{Value}

Values are related to custom values, religions, principles of life, habits where every individual has his own assessment of culture, customs, and buildings s/he visits (Ginting and Wahid, 2015). A place or building is essential since it has a value or meaning to someone. In the current research, the values assessed are related to socio-cultural values and historical buildings in the tourist area. 
The value provides a unique experience that could differentiate it from others (Lalli, 1992). The diversity of places is visible through the architectural style of heritage buildings, historical stories, cultural festivals, integrated accessibility with heritage buildings, and memories associated with childhood or past. This research concerns in physical and cultural values maintained through the existence of cultural activity and historical architecture.

Based on the result, most respondents assessed that the cultural activities are less attractive (local people 2.86; domestic tourists: 3.05; foreign tourists 3,64) (see Table 2). There are no longer events held on Sipiso-Piso. This is expressed concisely by the Head of ASITA (Association of the Indonesian Tours and Travel Agent of North Sumatra Province):

"Sipiso-Piso is attractive for its scenery. However, most tourists go there only for one hour because there are no activities there whereas the goals of successful tourism could be visible form how long they would stay. Sipiso-Piso still offers a great view of waterfall only to take some pictures". (Key Respondent: Head of ASITA)

The length and the frequency of visit indicate attachment to a place that plays an essential role in embedding place identity. A desire to maintain closeness to the particular objects is the main characteristic of attachment (Ujang, 2015) which associated with the special feeling created through the peculiarity of a place.

A place should have the peculiarity that could distinguishable from others. This distinction includes the attractiveness of historical object, historic building, cultural activity, and local product offered as well. The historical building visually revealed the continuity of the past where reflects the character of the place. One of continuity elements that construct the place identity is the existence of a wellpreserved historical building. Sipiso-Piso is infinitely landscape that offers excellent vista which is not intended for residential area inhabited by indigenous people. Therefore, the existence of historical building does not exist there, and respondent gave a low assessment (see Table 2). However, some local people regarded that the existing buildings (restaurant and gazebo) with eclectic architecture style (traditional roof of Karo Culture) was considered as historical buildings (see figure 2). This misperception occurred due to low understanding of the definition and meaning consist of historical building indeed.

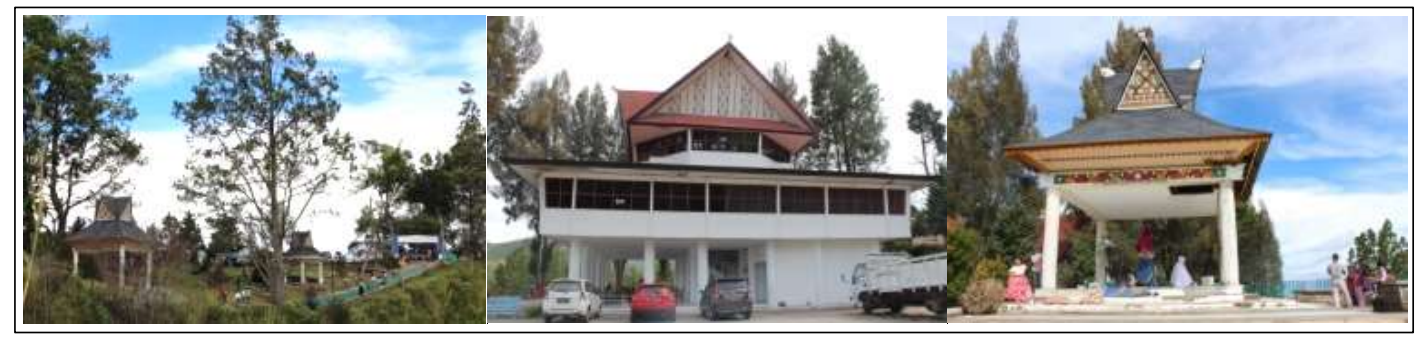

Fig. 2: Existing Buildings in Sipiso-Piso waterfall

\subsubsection{Nostalgia}

Lalli (1992) suggests that continuity is one of the principles constructing place identity which connects one's past and current life in the present. None could forget the area where s/he was born, because somehow the place has many memories, memory, and nostalgia therein when s/he was a child. Someone can reveal his identity from his residence where it will undoubtedly lead to personal experience in one's own life.

Nostalgia is defined as a unique positive memory or a collection of memories from the past that is capable of providing a more favorable alternative of answers from the present (Ramshaw \& Gammon, 2005 in Seifried \& Meyer, 2010). Holbrook and Schindler (1991) in Seifried \& Meyer (2010) indicated nostalgia as a preferred choice by someone. It is a personal and emotional feeling as people can be recalled of their past through specific objects or symbols (Gabriel (2000) and McMurray \& Pullen (2008) in Seifried \& Meyer, 2010). Physical elements, structures, and buildings can create feelings related to nostalgia because of the special meaning through symbols and experiences created (Fairley 2003). Holbrook and Schindler (2003) argue that individuals can form a bond with physical objects to connect experiences by assuming an object poses a memory of past experiences. In this case, unique traditions as nonphysical objects could also strengthen the relationship between humans and physical objects.

Nostalgia could facilitate continuity of identity through direct or vicarious experience which allows people to yield a sense of themselves as time travelers in a specific place. It may discover meaning in someone's life where integrating experience to understand oneself better. Previously, nostalgia has been associated with continuity; self-esteem; connectedness; social competence and satisfaction; social-emotional coping; goal-directed strategies and positive reframing (Batcho \& Shikh, 2016).

Based on the result, part of respondents confirmed that Sipiso-Piso waterfall is their hometown which represents a unique experience: (local people 2.72; domestic tourists: 2.36) (see Table 2). The particular memory recalled by respondent will evoke emotion. This includes childhood nostalgia being in Sipiso-Piso, playing around Sipiso-Piso waterfall, and attending the cultural event (local people 2.81; domestic tourists: 2.41) (see Table 2). The experience can be interpreted as episode memory, a memory that receives and stores events that occur or at certain times and places that serve as autobiographical references (Syah, 2003). That personal experience will make one recall and tell it to others. Other people who heard the pleasant experience from someone will imagine and soon be motivated to experience the same as the one who told. The memory would determine their decision to visit Sipiso-Piso in future which embedded continuity of the place. This continuity also expressed by key respondent in-depth interviews: 
"The number of tourists visiting Sipiso-Piso Waterfall is uninterrupted. Not less than 150 to 200 tourists come every day. It could increase three times in long weekends like New Year's Eve, Independence Day, Hari Raya of Eid, and Chinese New Year".

(Key Respondent: Tourism Figure of Karo Tourism)

"The most crowded tourism destination in Karo is Pasar Buah, then followed by Sipiso-Piso. There, we can see a great view of Sipiso-Piso waterfall. However, it still merely offer the natural potential. People go there for one or two hours only".

(Key Respondent: Tourism Figure of Karo Tourism).

This indicates that the experiences of past and nostalgia reflected through people and some tourists will maintain a continuity of the history (Goodwin et al., 2009). The experience will influence the environmental perception. However, most tourists revealed that it was their first visit came to Sipiso-Piso Waterfall. So, they have no memories of childhood or nostalgia being there. A tourist destination can improve the quality of the tourist experience if the place can give a feeling of nostalgia while visiting the there (Ginting \& Wahid, 2015).

Most respondents have a quite memorable experience at Sipiso-Piso Waterfall (local people: 3.17; domestic tourists: 3.00; foreign tourists: 3.29). Most of them truly enjoyed the view of Sipiso-Piso Waterfall and landscape of Lake Toba from height (see fig. 1). The direct experience created while going down the stairs to touch Sipiso-Piso Waterfall will allow to the personal experience of the tourists (see fig. 3). But the path that they must take when seeing Sipiso-piso Waterfall is hard and make them exhausted, kind of ruin their memorable experience there. Individual experience embedding positive perception would distinguish it from others (Ginting et al., 2017). Place identity is established when someone had a positive perception and attached to the place (Twigger and Uzzell, 1996).

Someone will value experience depending on their expectation, situation, context, and resources offered (Ginting et al., 2018). The result showed that most respondents did not have quite a positive perception toward Sipiso-Piso, they want to visit there again later but don't want to go down seeing Sipiso-piso Waterfall closely again (local people: 3.14; domestic tourists: 2,27; foreign tourists: 3.29 ). It is also expressed by the key-respondent in-depth interview:

"A lot of tourists that already come down and don't want to come again. They said they were exhausted and did not want to experience it anymore."

(Key Respondent: Local People/Merchant)

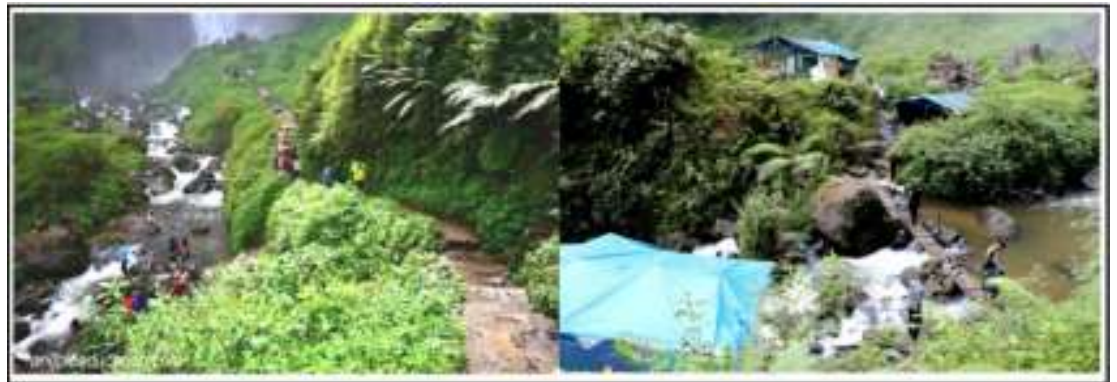

Fig. 3: View of Sipiso-Piso Waterfall

\subsubsection{Familiarity}

Familiarity is closely related to place identity where it is the main attribute associated to place attachment. It is closely associated with four dimensions (Hasanuddin, 2003 in Ujang, 2015). First is locational knowledge indicating the understanding of where the place is. Then, visual recognition, i.e., the ability to recognize the area. The next is place name-recognition, and the last is interaction with the place. Familiarity is integrated with the existence of the physical quality and activities within an area in making a meaningful place.

Ginting and Wahid (2015) stated that physical quality is indispensable for tourism areas to establish positive perceptions through the character forming elements. Someone would visit somewhere because s/he was impressed with the availability of well-maintained facilities in a tourist destination and the real natural attractions. Emotional attraction is reflected in the place ability to meet the psychological needs of people who evoke their emotions (Ujang, 2014). The questionnaire result showed that the availability of public facilities and accommodation perceived negative response (see Table 2). This is supported by an interview with the key respondent:

"The number of public amenities is still lacking, but we have provided so tourists can feel comfortable while visiting." (Key Respondent: Public figures at Sipiso-Piso Waterfall)

"Sipiso-Piso is the special God's gift which was born from nature. Compared to seven regencies in Toba Caldera, Sipiso-Piso is the one that has significant potential. Magnificient waterfall and the grand vista of Lake Toba are offered, yet the remaining problem is there is no integrating spatial planning for Sipiso-Piso. We are proposing the document next year.

(Key Respondent: Head of Karo Regency Tourism Planning Program)

In spite of having well-known geological heritage values and natural resources, Sipiso-Piso could necessarily be a Global Geopark unless it has a sustainable tourism plan. A master plan of public facilities; accommodation availability; ease accessibility; and natural, cultural and intangible heritage planning must be integrated as a unity of attraction in developing tourism planning. Sustaining the attraction and place meaning is important to create the familiar and meaningful place to people. 
A secure connection to familiar place will contribute in embedding sense of belonging (Ujang, 2008) which takes a role in place identity. Familiarity impacts on comfort degree which is essential in developing the attachment to the place (Ujang, 2012). Instead of providing master tourism planning, the role of indigenous people in proposing Toba Caldera as UGG member also becomes the main subject contributing and managing the tourism development. The result indicates that respondents, especially domestic tourists, gave a low assessment for the affability of the local community (see Tabel 2).

Indigenous people's knowledge contributes to preserving a place. They must be continually active in promoting their authentic culture as the requirement of UGG member where the local community is the key resource. Community empowerment must participate to utilize the resources optimally for social and economic welfare. Indeed, Toba Caldera Geopark must involve the Batak's culture wisdom in all elements in supporting the program where must be synergized with the natural environment, and culture.

\subsection{Conclusion}

The study suggests that past experience is required through cultural activity and history in sustaining place identity. A place has meaning since it reminds us through nostalgia and attachment created where it would influence the intensity of visit continually. Since Sipiso-Piso merely offers natural resources only without remarkable attraction, it is crucial to support it as attractive geo-area. Hence, preserving environment instead of maintaining the cultural value is essential to be done in preparing Toba Caldera as UGG member. However, community involvement and participation exceedingly take an active role as well as. Calling back the authentic indigenous culture would create strong perception created through value, nostalgia, and familiarity. In this case, community empowerment is genuinely encouraged to utilize the resources optimally. In preparing Toba Caldera Geopark, socialization of Toba Caldera Geopark must be conducted to the local community for embedding their role as the primary stakeholder involved. Thus, the author recommended further research on how to improve the continuity in this area.

\section{Acknowledgements}

This research is made possible without the grant given by Ministry of Education and Culture of Indonesia. Authors gratefully acknowledge the contributions of participants specially all students of Department of Architecture, Faculty of Engineering, University of Sumatera Utara.

\section{References}

Batcho, I.K. \& Shikh (2016). Anticipatory Nostalgia: Missing the present before it's gone. Journal Personality and Individual Differences 98 (2016) $75-84$

Breakwell, G. M. (1993). Identity Process Theory: Identity, Social Action and Social Change.Cambridge University Press.

Fairley, S. (2003). In search of relived social experience: Group-based nostalgia sport tourism. Journal of Sport Management, 17(3), 284-304.

Fisher, D. (2006). Perception of Heritage-a Theoretical Analysis. Cutting Edge Research in Tourism, New Directions Challenges an Applications School of Management, University of Surry, UK. 6-9 June 2006

Gabriel, Y. (2000). Storytelling in organizations. Oxford: Oxford University Press.

Ginting, Nurlisa \& Wahid, Julaihi. (2015). Exploring Identity's Aspect of Continuity of Urban Heritage Tourism. Procedia Social and Behavioral Sciences, 202, 234- 241

Ginting, N., Rahman, N. V., Nasution, A. D.(2017). Increasing Tourism in Karo District, Indonesia Based on Place Identity. Environment Behaviour Proceedings Journal

Ginting,N., Rahman,N.V., Nasution, A.D., Widya A.T.,(2018). How Manageable a person feels the place to be: self-efficacy in supporting tourism. IOP Conference Series: Materials Science and Engineering, Volume 309, conference 1

Goodwin, H., Santilli, R., \& others. (2009). Community-based tourism: A success. ICRT Occasional Paper, 11(1), 37

Hasanudin, L. (2003). A Comparative analysis of perception of urban landmarks between designers, non-designers and laypublic: Kuala Lumpur Malaysia.Unpublished PHD Thesis, University of Sheffield.

Holbrook, M.B. and Schindler, R.M. (2003). Nostalgic bonding: Exploring the role of nostalgia in the consumption experience. Journal of Consumer Behavior 3 (2) 10727.

Korpela, M. Kalevi (1989). Place-identity as a product of environmental self-regulation. , Journal of Environmental Psychology, 9, 241-256

Lalli, Marco. (1992). Urban-Related Identity: Theory, Measurement, and Empirical Findings. Journal of Environmental Psychology, 12, 285-303

Ramshaw, G (2005, April). Nostalgia, heritage, and imaginative sports geographies: Sport and cultural landscapes. Paper Presented at the Forum UNESCO University and Heritage 10th International Seminar "Cultural Landscapes in the 21stCentury," Newcastle upon Tyne, UK.

Simatupang K.(2016). An analysis of Toba Caldera Geopark Discourse in North Sumatra Province of Indonesia, Environmental Politics the Conference in Department of Political Science, Tunghai University. 
Savage, M., Bagnall, G. and Longhurst, B. (2005) Globalization and Belonging. London: Sage.

Syah Muhibbin. (2003). Psikologi Belajar. Jakarta: PT Raja Grafindo Persada.

Twigger-Ross, C. L., \&Uzzell, D. L. (1996). Place and Identity Process. Journal of Environmental Psychology, 16, 205-220.

Ujang,N. (2008). Place Attachment, Familiarity and Sustainability of Urban Place Identity. Jurnal Department of Landscape Architecture, Faculty of Design and Architecture, University Putra, Malaysia

Ujang, N. (2012). Place attachment and continuity of urban place identity.Procedia-Social and Behavioral Sciences, 49, 156-167.

Ujang, N., \& Zakariya, K. (2015). Asia Pacific International Conference on Environment Behaviour Studies (AicE-Bs 2014Berlin), Sirius Business Park Berlin-yard field, Berlin, Germany, 24-26 Place Attachment and the Value of Place in the Life of the Users. Procedia - Social and Behavioral Sciences, 168, 373-380.

UNESCO. 2006. GLOBAL GEOPARK NETWORK.Yunani: Lesvos Petrifi ed Forest

Ujang, Norsidah. (2012). Place attachment and continuity of urban place identity. Procedia-Social and Behavioural Sciences, 49, 156-167

Yaldiz, E.,Aydin, D., Siramkaya,S.B.,(2014). Lost of City Identities in The Process of Change: The City of Konya-Turkey. Procedia Social and Behavioral Sciences, 140, $221-233$

Yuen, B. (2005). Searching for place identity in Singapore. Habitat International, 29(2), 197-214. 